\title{
Groei, differentiatie en pathologie
}

Citation for published version (APA):

Arends, J. W. (1988). Groei, differentiatie en pathologie. Maastricht University. https://doi.org/10.26481/spe.19880520ja

Document status and date:

Published: 20/05/1988

DOI:

10.26481/spe.19880520ja

Document Version:

Publisher's PDF, also known as Version of record

\section{Please check the document version of this publication:}

- A submitted manuscript is the version of the article upon submission and before peer-review. There can be important differences between the submitted version and the official published version of record.

People interested in the research are advised to contact the author for the final version of the publication, or visit the DOI to the publisher's website.

- The final author version and the galley proof are versions of the publication after peer review.

- The final published version features the final layout of the paper including the volume, issue and page numbers.

Link to publication

\footnotetext{
General rights rights.

- You may freely distribute the URL identifying the publication in the public portal. please follow below link for the End User Agreement:

www.umlib.nl/taverne-license

Take down policy

If you believe that this document breaches copyright please contact us at:

repository@maastrichtuniversity.nl

providing details and we will investigate your claim.
}

Copyright and moral rights for the publications made accessible in the public portal are retained by the authors and/or other copyright owners and it is a condition of accessing publications that users recognise and abide by the legal requirements associated with these

- Users may download and print one copy of any publication from the public portal for the purpose of private study or research.

- You may not further distribute the material or use it for any profit-making activity or commercial gain

If the publication is distributed under the terms of Article $25 \mathrm{fa}$ of the Dutch Copyright Act, indicated by the "Taverne" license above, 


\section{Groei \\ Differentiatie \\ en \\ Pathologie}

Rede uitgesproken bij de aanvaarding van het ambt van gewoon hoogleraar in de pathologie aan de Rijksuniversiteit Limburg op vrijdag 20 mei 1988

Dr. J.W. Arends 
Mijnheer de Rector Magnificus,

Dames en Heren Leden van het Uninersiteirsbestur.

Dames en Heren Leden van de Universiteilsraad,

Dames en Heren Hoogleraren, Docenten en Leden van de Wetenschappelijke Staf,

Dames en Heren Leden van Bestuur en Directie van het Academisch Ziekenhwis,

Dames en Heren Leden van de Technische en Administratieve Staf.

Dames en Heren Studenten,

en voorts Gij allen, die door Uw aanwezigheid van Uw belangstelling blijk geeft,

Zeer gewardeerde toehoorders,

In een van de vele zalen van de overvolle schilderijengalerij van het Palazzo Pitt te Florence hangt op een onopvallende plaats haast tegen het plafond reikend een portret van een van de bekende Italiaanse renaissance kunstenaars: Titiaan, enige tijd schilder aan het hol van Keizer Karel V. De geportretteerde, hofarts van deze Keizer, is niemand minder dan de in medische kringen alom bekende Andreas Vesalius. Wij zien Vesalius op het doek afgebeeld staande voor een goed gevulde boekenkast.

Voor hem bevindt zich een tafel met een opengeslagen boek, waarop zijn linker hand rust. Hoewel de titel van het boek op het portret niet uit komt, lijdt het nauwelijks Iwijtel dat Vesalius' hand gelegen is op een van de delen van "Peri chreias moorioon, Over de doelmaligheid der lichaamsdelen"', geschreven door de Romeinse arts Galenus. Diens in dit opus magnum vervatte anatomische en fysiologische denkbeelden golden gedurende ruim anderhalf millenium voor de medische wereld als het absolute leergezag. In zinn rechierhand, aarzelend, haast nog achter de rug verborgen, maar niettemin duidelijk zichtbaar, houdt Vesalius een schaar. De eerste moderne anatoom, of - beter gezegd - een van de eersten in de geschiedenis van de geneeskunde, die zich liet leiden door met nuchtere waarneming en experimenten verworven feiten. zien we aldus door de kunstenaar gekarakteriseerd als een 
overgangsfiguur. Vesalus had immers door systematisch onderzoek alle teiten in handen om een einde te maken aan het Galenische paradigma. Hil kritiseerde Galenus' denkbeelden dan ook heftig. maar heeft uteindelik de genadeslag niel kumen, of misschien durven. loedienen. De tijd daarvoor was pas ongeveer een eeuw later rip en aan Harvey komt de eer toe definitiel met de Galenische denkwereld afgerekend te hebben. Deze gang van zaken vinden we op zeer boeiende wijze beschreven in het boek "Het menselijk lichaam" van Prof.dr. J.H. van den Bierg. Ik heb dit portret uiteraard niet bij U geintroduceerd om een kunsthistorische analyse te bieden van het psychologisch raffinement, waar Titiaan bekend om staat, noch om er diepgaande bespiegelingen over "Sternstunden" in de geschiedenis en onfwikkeling van de geneeskunde aan vast te knopen. Min bedoeling is alleen on via de op het portret afgebeelde attributen. boek en instrument. een ingang te hebben, die mij woeiend breng: tot de thematiek, die ik vammiddag met $U$ aan de orde wil stellen. Het instrument beschouw ik hierbij als symbool van de experimentele insteling, die vooral na opname in de stroom van de positivistische benadering in de natuurwetenschappen vanaf de vorige eeuw geleid heeft tot een indrukwekkende groei en daarmee onvermijdelijk gepaard gaande differentiatie van de medische kennis en kunde. Het boek, of het geschreven woord, eertijds symbool van leergezag, heeft in deze ontwikkeing een verandering van symboolfunctie ondergaan en staat nu voor de communicatie, die bij snelle groei en differentiatie onontbeerlijk is. Boek en instrument, beide symbolen voor groei en differentiatie, de twee begrippen, die ik vanmiddag zoveel mogelijk als leiddraad zou willen gebruiken voor een uiteenzetting over enkele lacetten van oncologisch onderzoek in de pathologie en een schets van mijn wisie op de huidige stand van zaken en toekomstige ontwikkelingen in de klinische pathologie.

Eerst wil ik U meevoeren op een kleine rondgang langs het onderzoek, dat op onze afdeling plaats vindt, vooral, om $U$ een idee te geven van de achtergrond en de ideeen, van waaruit dit onderzoek wordt bedrewen.

Dat abnomale groei tot een van de meest in het oog springende kemmerken van kanker behoort, is zelfs de leek maar al te bekend. De kankercel toont ook een stoornis in de differentiatie. Door sommige onderzoekers wordt deze differentiatiestoornis zelfs als het belangrijkste verschijnsel gezien. Pierce bijvoorbeeld spreekt van 4 kanker als "a disease of differentiation". Het oncologlsch onderzoek 
hier in Maastricht is dan ook bijeengebracht in een deeproject, dat als thema meekreeg "Groei en Differentiatie". Uit deze mededeling mag overigens ook duidelik worden, dat de keuze voor de litel, die ik aan deze rede heb meegegeven, voor een deel op deze omstandigheid is gebaseerd. Een belangrijk deel van het oncologisch onderzoek, dat wij verrichten, is geconcentreerd op kanker van de dikke darm. In Nederland worden jaarlijks ongeveer 5000 patiënten door deze ziekte getroffen. Na viff jaar blijkt ongeveer de helft van deze patienten te zijn overleden, meestal tengevolge van uitzaaiing naar de lever. Uit deze gegevens blijkt, dat dikke darmkanker een van de meest frequent voorkomende soorten van kanker is (in Nederland de tweede plaats innemend na longkanker bij de man en borstkanker bij de vrouw) en bovendien. dat de resultaten van de behandeling pover genoemd moeten worden. Dit klemt des te meer, als men bedenkt, dat er in de laatste decennia eigenlijk geen vooruitgang in de bestrijding is geboekt. Chirurgische verwijdering van het proces is het enige wapen, dat ter beschikking staat; voor andere modeme vomen van kankertherapie zoals bestraling en celdelingremmende middelen, is de tumor betrekkelik ongevoelig. Een van de problemen is, dat er nauwelijks inzicht bestaat in het nogal diverse gedrag van de tumor en daarom het beloop bij de individuele patient slecht voorspelbaar is. De klassificatie op grond van de uitbreiding van het proces in het operatiepreparaat, reeds voor de tweede wereldoorlog door de Engelse patholoog Dukes opgesteld, is in feite nog steeds de enige, met behulp waarvan patienten kunnen worden verdeeld in vier groepen met een duidelijk verschil in levenswerwachting. Zo blijkt grosso modo van patiënten bij wie de tumor nog niet door de gehele darmwand is gegroeid (stadium A) na vijl jaar nog 90\% in leven. Wanneer het proces echter wel het buitenoppervlak van de darmwand heeft bereikt (stadium B), daalt het wiff jaars overlevingspercentage tot $60 \%$, terwij een daling tot $40 \%$ gezien wordt bij patiënten met een tumor, die reeds naar de locale lymfklieren is uitgezaaid (stadium C). Het slechtst is thet gesteld met patiënten, bij wie durante operatione al uitzaaling in de lever blijkt te hebben plaatsgevonden of de tumor in naburige organen is ingegroeid (stadium D). Van deze patiënten is na vijf jaar nog slechts $10 \%$ in leven. Hoewel door onderzoek van het operatiepreparaat op uitloreiding van het proces aldus enig inzicht in de verdere vooruitzichten van de patient kan worden verkregen. resteren er legio vragen, zoals, waarom overlijd nog $40 \%$ van de patienten met een tumor, die niet was uitgezaaid, ol vice versa, waarom overleeft $40 \%$ van de patienten met een uitgezaaide lumor 
Men zou denken, dat er binnen een bepaald stadum van tumoruibreiding op zijn minst twee categorieên patienten te vinden zijn met een verschil in klinisch beloop. Zou dit werschil in klinisch beloop veroorzaakt worden. omdat er sprake is van meerdere kankertypen bestaande uit cellen met hun eigen karakteristieken en biologisch gedrag? Uit mortologische verschilen blikt dit niet: de meerderheid der dikke darmitumoren toont een tamelikk uniform beeld.

Rum een decennium geleden bevond men zich op een ander terrein wan kankeronderzoek, dat van kankers van lymfklieren, in een min of meer analoge siluatie. Men onderscheidde groot- en kleincellige kankertypen en kon als zeer globale stelregel hanteren. dat de vooruitzichten voor een patient slechter werden naamate er sprake was van een grootcelliger type.

Het aantal uitzonderingen op deze regel was echter zo groot, dat het moeilik was er van te bliven uitgaan, dal uitzonderingen de regel nu eenmaal bevestigen. De in de lymfklier huizende cel is de lymfocyt die een centrale rol speelt in de immunologische afweer. Mede door de stimulans, die uitging van onderzok op het gebied van de transplantatie geneeskunde, heeft de discipline van de immunologie zich enorm kunnen ontwikkelen, hetgeen onder meer heeft geleid tot de herkenning van meerdere functioneel van elkaar verschillende soorten lymfocyten en de definiering van celreeksen in de ontwikkeling en rijping daarvan. Deze ontwikkelingen brachten onderzoekers op het terrein van lymlklierkanker op het idee te onderzoeken, of de kennis van de lymfocytenriping en -functie toepasbaar was voor hel onderscheiden van meerdere kankertypen. Op basis van de gedachte, dat lymfocyten in het kader van kwaadaardige ontaarding geremd worden in een bepaalde fase van rijping en daarna min of meer de daarin verworven functionele eigenschappen als kankercel bewaren, bleek het inderdaad mogelijk vele voor een groot deel morfologisch identieke lypen kanker in functioneel verschillende typen te onderscheiden. Dit heeft geleid tot nieuwe lymfoom klassificaties, die een meer gedifierentieerd inzicht geven in het biologisch gedrag van deze typen, hun klinisch beloop bij patienten alsmede hun reactie op behandeling.

Tegen de achtergrond van deze ontwikkeling leek het vruchtbaar ook op dikke darmkanker een lunctionele benadering aan te wenden en te pogen tot een indeling van meerdere functionele types te komen. Nomaal dikke darmslimwles herbergt drie verschillende celsoorten in de deklaag, op aard en functie waarvan ik thans niet nader wil ingaan. Recent onderzoek heeft aannemelijk 
stamcel, waarvan de progenituur langs drie differentatielinen Litrijpt, via overigens bij de mens nog slecht gedefinieerde tussenstadia. De cellen van deze verschillende difterentiatielinen kunnen worden gekarakteriseerd aan de hand van met hun funclie verband houdende specifieke celproducten, die voomamelijk met behulp van zogenaamde immunocytochemische technieken in weefsels zichtbaar kunnen worden gemaakt. Wii pasten deze bewerking toe op dikke darm tumor weefsel wan een door de afdeling heelkunde in het kader van een klinische trial samengestelde patiëntenserie, waarvan het verloop van de ziekte nauwkeurig was gedocumenteerd. Uit dit onderzoek kwam naar woren, dat de aan- of afwezigheid van de meeste specifieke celproducten in het kwaadaardige proces enig verband hield met de overleving van patiënten.

Niettemin kwamen wij enigszins bedrogen uit in de verwachting. dak het mogelijk zou zijn dikke darm kanker le klassificeren aan de hand van cle drie normaal in het slijmulies voorkomende celtypen met een subtypering naar de ontwikkelingsstadia daarvan.

Vele tumoren toonden namelijk meerdere differentiatie kenmerken. soms zelfs in één tumorcel. Kennelijk zijn de drie differentiatielinen. althans in de tumorcel van de dikke darm, niet stringent gescheiden. Voorts bleek het frequent woor te komen dat niel alle tumorcellen een differentiatie kenmerk vertoonden. Men moet dus aannemen, dat een tumor is opgebouwd uit meerdere cellypen, die niet allemaal hetzelfde stadium of type van uitrijping laten zien.

Tenslotte bleek in een multivariant analyse, die inzicht verschaft in de sterkte van de relatie met overleving en de onafhankelijkheid ten opzichte van andere overlevingsgerelateerde kenmerken, dat de door ons bestudeerde kenmerken bij lange na niet uit de schaduw van de reeds aangehaalde stadiumindeling volgens Dukes traden. Hoewel de mogelikheid bestaat dat wili niet de goede kenmerken hebben gekozen om onze uilgangshypothese te testen, lijkt het achteraf gezien - waarschinnliker, dal we zinn uitgegaan van een niet geheel juiste gedachte. Er zijn namelitk goede gronden om te veronderstellen. dat tumorweefsel zich voor een groot deel houdt aan de wetten, die gelden voor groei en differentiatie van normaal weefsel. In dat geval moeten wij aannemen, dat het groeigedrag en het verdere beloop van een kwaadaardig proces vooral athangt van het voorldurend in deling verkerende, progenituur genererende, nog ongedifferentieerde Lumorstamcel compartiment en niet zo zeer van de merendeels rustende, hun functie uitoefenende, min of meer gedifferentieerde cellen, die hieruit voortkomen. Het onderzoek zou zich daarom moeten richten op de tumorstamcel, die zich echter - 
just vanwege zin gebrek aan differentiatie kenmerken - slecht laal karakteriseren en identificeren. Hier kan echter de hulp worden ingeroepen van technieken, die op het terrein van de moleculaire biologie ziln ontwikkeld. Op het gebied van de moleculaire biologie doet zich op dit moment een revolutie voor na de ontdekking van kankergenen (oncogenen), die onder andere mogelijk werd gemaakt door nieuwe technologie, waarbij kleine stukjes erfelijkheidsmateriaal (zogenaamde probes) in grote hoeveeheden kunnen worden geproduceerd. Bij een problitererende cel zijn andere genen actief dan in een rustende functionerende cel. Hel aantonen van de actieve genen en de daarvan afgeleide informatie overcragende moleculen door middel van probes opent een mogelikheid deze cel te identificeren.

Het totaal overziend zouden we kunnen stellen wat wij ons in de functionele benadering van dikke darmkanker lot duswerre te veel hebben gericht op het aspect van differentiatje, terwijl er aanwijzingen bestaan dat tenomenen van groei een meer bepalende roll in het gedrag van deze tumoren spelen. Min collega Bosman heeft onlangs een project uitgeschreven om de onderzoekslijn meer in deze richting om te buigen.

U zult begrijpen, dat een functionele typering vanuit in essentie statisch onderzoek op patiëntenmateriaal hoogstens leidt tot een momentopname en dat voor een meer dynamische studie van het groei en differentiatie proces experimentele modellen, die voornamelijk afkomstig zijn uit de celbiologie, miet gemist kunnen worden. Parallel aan de bovengeschetste onderzoekslijn zijn dan ook dikke darm kanker cellen in kweek gebracht en stukjes tumor geimplanteerd in zogenaamde naakte muizen, die vanwege een stoornis in hun afweer menselijk weefsel niet afstoten en zo bestudering van groei en differentiatie van dit weefsel over langere tijd mogelijk maken. Recent is het zelfs door manipulatie mogelijk gebleken uitzaaing van zo'n geimplanteerd stukje menselik dikke darm kankerweefsel naar de lever van de naakte muis te verkrijgen. Dit opent perspectieven voor verdere bestudering van het uitzaaingsproces, dat, zoals ik $U$ in de inleiding reeds meedeelde. voor patiënten mel dikke darm kanker in de meeste gevallen de direcle doodsoorzaak vornt.

Ik hoop U met deze globale schets van een deel van ons kankeronderzoek duidelijk gemaakt te hebben, dat voor een functioneel gerichte aanpak naast de traditionele in de pathologie gebruikte lechnieken, methoden en techmieken uit de celbiologie en de moleculare biologie nodig zijn. sterker nog, hiervan een integraal 8 onderdeel dienen uit te maken. Tevens zult U hopelijk inzien, dat 
een dergelike geintegreerde aanpak hoopvolle perspectieven voor het dikke darmkanker onderzoek biedt.

Voor ik deze rondgang door het onderzoek in het deelproject "Groei en Differentiatie" afstuit om over te gaan tot het belichten van enkele ontwikkelingen in de klinische pathologie, lijkt het mij goed $U$ er met nadruk op te wijzen, dat slechts eén lin van onderzoek werd belicht. Een analyse van het gedrag van kankercellen in het menselijk organisme vanuit de optiek van de kenmerken van de tumorcel per se zou immers een onverantwoorde beperking inhouden; ook de interactie van tumorcellen met het omgevende normale weelsel van de gastheer dient hierin te worden betrokken. Een belangrijk deel van ons onderzoek concentreert zich dan ook op dit lacet van het kankeronderzoek, terwij het locus in de toekomst wellicht nog meer naar de kant van de gastheer reacties op tumorgroei zal moeten worden gericht.

In zijn rede getiteld "Pathologie en Gespecialiseerde Kennis" uitgesproken bij de aanvaarding van hel ambt van hoogleraar in de algemene ziekteleer en ziektekundige ontleedkunde aan de Rijksuniversiteit te Groningen, thans én en dertig jaar geleden, schetste mijn vader ter illustratie van zinn visie op de pathologie de geschiedenis van de ontrateling der pathogenese van het ziektebeeld pernicieuze anaemie.

Het zij mij vergund aan de hand van enkele citaten uit deze rede de meest wezenlike kenmerken van zijn gedachten over de pathologie aan $U$ woor te leggen.

"In deze summiere beschrijing van de successievelik verworven kennis van het ziektebeeld der pernicieuze anaemie is de gehele historische ontwikkeling van het geneeskundig onderzoek van de laatste honderd jaar af te lezen. Zoals zovele ziekten is ook pernicieuze anaemie een aandoening, die in de vorige eeuw op grond van structuuralwikingen geclassificeerd kon worden. Hel is bij pernicieuze anaemie nu eens niet de patholoog anatoom geweest die door postmortale onderzoekingen de kenmerkende veranderingen aan het licht heeft gebracht, doch de klinicus, die in tijdens het leven onderzocht materiaal - namelijk het bloed en beenmerg - deze varmafwijkingen heeft ontdekt. Geleidelijk is men dan tot het inzicht gekomen dal de hogere en betekenisvolle eenheid wan het organisme niet door mortologische beschouwing aleen aan het licht is te brengen, doch dat naast de structuur tegelik de functie en de stofwisseling in ogenschouw moeten worden genomen".

In mijn vaders visie dient de patholoog "geheel doordrongen te zijn 
van het felt dat een wormenleer, die zich tot het uislutend descriptieve beperkt, geheel steriel is. Daarvoor heeft de ontwikkeling van de pathologie te duidelik aangetoond, dat vorm en functie bij elkaar behoren en van ek kaar athankelik zinn en dat de vomenleer pas levend kan worden, als steeds getracht wordt in de structuur de functie af te lezen". Sterk wordt in de rede benadrukt. dat woor deze benadering wan de pathologie inbreng vanuit verschillende deek en differentiatie velden en andere specialistische disciplines noodzakelijk is. "De specialisatie, een gevolg van de zich steeds uitbreidende grenzen in de pathologie, houdt bij eerste beschouwing het grote gevaar in, dat er nog een toenemende verbrokkeling en desintegratie zal ontstaan. Er zijn echter in de praklik aanwijzingen van hel omgekeerde, namelijk dat juist de specialisatie de mogelikheid schept tot een integratie op een hoger niveau. leder, die enigszins op de hoogte is met de feiten, kan waarnemen, dat de onderzoeker met gespecialiseerde ervaring op een gegeven moment op het toppunt van zijn geisoleerde kennis gekomen, deze isolatie onclergaat als een rem voor zinn verdere ontwikkeling en daardoor de behoefte gaat voelen om contact met zijn butuman op te nemen: een tendentie dus tot horizontale uitbreiding".

In het verlengde van de gedachten van zijn leermeester en voorganger de Maastrichtenaar Vos (welk een onverwachte cirkel wordt hier gesloten) vat mijn vader zijn visie samen in een vergelliking van de pathologie met een bouwwerk. ".........zal hel U niet verwonderen, dat juist in deze tijd met zijn revolutionaire wetenschappelijke wooruitgang het bouwwerk van de pathologie voortdurend aan verandering onderhevig zal zijn. Het spreekt haast vanzelf, dat er incongruente delen zullen ontstaan, die op een gegeven moment revisie of misschien zelfs afbraak moeten ondergaan, doch het algehele bouwplan met zijn zuilen van gespecialiseerde kennis en daarboven de groei van een horizontaal platond is gezond".

Ik hoop U gedurende de kleine rondgang langs het onderzoek dat op onze atdeling plaats vindt, te hebben geilustreerd, hoe minn vaders rum dertig jaar geleden geute gedachten over de palhologie in het moderne onderzoek vorm hebben gekregen en ook duidelijk le hebben gemaakt dat zin optimisme omtrent de soliditeit wan het algemene bouwplan gerechtvaardigd is gebleken. Om de vergelijking nog heel even door te trekken: celbiologie en moleculaire biologie hebben immers een vaste plaats in dit bouwplan verkregen.

10 Het gebouw van de pathologie is ondanks toenemende groei en 
differentiatie van het vakgebied intact gebleven door zim homzontale platonds, of - om het in meer modeme temen weer te geven - door het leggen van dwarsverbanden op grond van een primaire gerichtheid op het bestuderen van "mechanisms of disease". Geldt deze constatering ook voor een deel van het gebouw, de klinische patholggie? Gaarne zou ik hierover enige gedachten ontvouwen.

Het naar de klinek gerichte ded van de pathologie draagt als éen van de officieel geregistreerde medische specialismen de naam pathologische anatomie, de beoefenaren van dit specialsme worden aangeduid als patholoog-anatoom. In vrijwel iedere rede van een hoogleraar in de pathologie word in meer of mindere mate onvrede over deze officiële benaming geuit. Ook ik koester bezwaar tegen de naamgeving vanwege de negatieve associaties, die opgeroepen worden in verband met historische ontwikkelingen in de pathologie en de gerechtelike pathologie, maar vooral varwege het feit. dat in deze terminologie het morfologisch aspect van ons werk te sterk benadruk! wordt. Op basis wan de klinische gerichtheid word wel gesproken over klinische pathologie, welke term ik vanmiddag ook zou wilen hanteren. Het zou mij echier te ver gaan de officiele benaming van ons specialisme in cleze zin om te dopen, zoals door sommigen gesuggereerd wordt, ondat in die naamgeving het integrale verband met de algemene pathologie verloren dreigt le gaan.

Deze constatering brengt mij onmiddellijk tot het beiljen van een credo. Het specialisme pathologische anatomie is ontstaan uit de pathologie als onderzoeksdiscipline, waarin zoals we hebben gezien, juist het integreren van vanuit verschillende disciplines aangedragen intormatie in termen van het ziekteproces als totaal centraal staat. Naar mijn stellige overtuiging behoort deze neiging tot integreren van delen tol een groter geheel ook - hoewel misschen iets minder expliciet onderceel te zinn van de allitude van de klinisch patholoog. Ten gevolge van groei en differentiatie in het wakgebied is uiteraard een zekere concentratie van de individuele patholoog op bepaalde aandachtsgebieden onvermijdelijk, zelts nuttig en gewenst; de band mel hel grotere geheel mag echter niet worden doorgesneden en voor een officiele status - in welke vorm dan ook - van deze aandachtsvelden is in min visie binnen het gebouw van de kinische pathologie geen plaats. In een Amerikaans tijdschrift is de patholoog-anatoom als "the last generalist" binnen de muren van hel ziekenhuis betiteld. Ik hoop bij min klinische collegae niet als al te pretentieus over te komen als ik bij deze de wens uitspreek, dat dit zo mag bliven. 
Misschien vorm het binnendringen van factoren van onzekerheid in onze dagelikse werkaamheden een der oorzaken van de toenemende tendens tot subspecialisatie die valt waar te nemen. Veranderingen in de gezondheidszorg hebben mede tot de introductie van onzekeneid in de patholoog-anatomische diagnostiek geleid. Steeds eerder - en ook vaker - wordt op de voorzieningen een beroep gedaan en de mogelikheden van diagnostiek zijn in rume mate toegenomen.

Terwill oude indelingen wan de verschillende ziektebeelden vooral gebaseerd waren op de structurele veranderingen, die zich in het weefsel van de patient in de eindfase van zijn aandoening hadden voorgedaan, wordt de patholoog thans in toenemende mate gecontronteerd met materiaal van vroege ziektefases, waarin de vertrouwde awwikingen begripelijkerwijs nog niet of nauwelijks uilgesproken zijn. Voorts kamen door het meer frequente appel op de voorzieningen en de meer vertinde diagnostische technieken steeds vaker zogenaamde lomes frustes, weinig uitgesproken vormen van een ziekte, en ook tussenvormen aan het licht. Oude nosologische indelingen bieden steeds minder houvast en de patholoog, die vaak gewend was het eindoordeel uit te spreken, het laatste woord te hebben, wordt gedwongen tot het bettreden van een terra incognita.

Daarbij komt bowendien, dat hij steeds minder materiaal tot zijn beschikking krijgt. Een uiterste wordt bereikt in de zogenaamde aspiratie cytologie, waarbij met behulp van een in een tumor gestoken naald en vacuüm getrokken spuit enkele - ook nog uit hun onderling verband gerukte - cellen uit hel proces worden geluxeerd en in de spuit worden opgezogen. De kenmerkende veranderingen van het proces kunnen dan worden gemist in thet verkregen materiaal, zodiat het soms onmogelijk is een uitspraak te doen, of een slag om de arm moet worden gehouden.

Collega van Engelshoven gaf in zijn onlangs gehouden rede aan, dal de radiodiagnostiek zich naar zijn mening bevindt op een weg naar meer zekerheid. Met enige overdriving zou ik willen zeggen. dat voor de klinische palhologie het omgekeerde geldt, althans voor zover het een vorm van onzekemeid betreft, die misschien beter als bescheidenheid omschreven zou kunnen worden. De vraag is namelik. wat precies onder onzekerheid moet worden verstaan. Een bepaalde mate van onzekerheid behoort naar min idee tot de attitude van een laat wintigste eeuwse wetenschapsbeoefenaar. In de natuurwetenschappen is men gedurende de laatste decennia lot het inzicht gekomen, dat de werkelijkheid als zodanig zich niet in

12 wetmatigheden laat beschrijven. Men kan hoogstens modellen 
ontwerpen en daarmee toetsenderwis de werkelikheid zo goed mogelijk benaderen. Ik heb wel eens de indruk dat de geneeskunde in dit opzicht paradigmatisch achterloopt bij de zuster natuurwetenschappen. Ook wij dienen ons er altijd van bewust te zijn, dat onze ideeën over ziekte en gezondheid en onze indelingen van verschillende ziekteprocessen uiteindelijk voortspruten uit het menselik brein. We moeten ons daarom realiseren, dat wij werken met voor slechts een deel bil onderlinge atspraak gemaakte en verder voomamelijk door intuitie bepaalde modellen, die de rijk in nuances geschakeerde werkelijkheid zo goed mogelik afspiegelen, maar slechts als menselike concepten deel van die werkelijkheid zelf uitmaken. De vraag bijvoorbeeld, of een ongedifferentieerde tumor op grond van een enkel spaarzaam met behulp van een geavanceerde techniek gevonden differentiatie kenmerk als behorende tot de groep, waarin dergelijke kenmerken veelwuldig worden aangetroffen, moet worden gerekend, is alleen te beantwoorden, wanneer ten aanzien van dit criterium duidelijke definities zijn vastgelegd en wordt eigenlijk pas relevant, wanneer blikt dat deze tumor zich ten opzichte wan zijn morfologische soortgenoten onderscheidt in zijn klinische beloop of reactie op behandeling. Zolang dit niet geconstateerd is, is het beter de collegae klinici mededeling te doen wan de vondst van het kenmerk en cle verdere classificatie van de tumor in het midden te laten dan een apodictische classificerende uitspraak te doen. De eerstgenoem de uitspraak wormt wellicht een prikkel tot verder onderzoek, de tweede daarentegen biedt slechts schijnzekerheid. Ik heb deze min of meer wetenschapsfillosofische uitweiding niet gemaakt om een bespreking van een controntatie met wezenlijke onzekerheidsfactoren in de diagnostiek uit de weg te gaan. in hun boek "Philosophy of medicine" constateren Wulf en anderen, dat de klinische geneeskunde zich bevindt in een periode van paradigmatische instabiliteit. De negentiende eeuwse natuurwekenschappelijke denkwijze, gekenmerkt - houdt U vast pathologen! - door de begrippen structuur en tunctie, wordt naar hun mening sinds de jaren zestig als ontoereikend ervaren. Rivaliserende theorieën zijn volgens de auteurs vanaf die tijd ontstaan en krijgen langzamerhand gestalle in de epidemiologie en de besliskunde.

Ik hoop U met de bespreking van ons onderzoek te hebben laten zien, dat denken in structuur en functie zelfs in de jaren tachtig nog tot vruchtbare resultaten en hoge verwachtingen kan leiden en $U$ zo juist te hebben duidelijk gemaakt, dat de geneeskunde wellicht in een ander opzicht paradigmatische moellikheden ondervindi. Dat 
epidemiologie en bestiskunde zich als kristallisatie kemen voor een nieuw paradigma aandienen wens ik daarom apert le bestrijden. Niettemin ben ik ervan overtuigd. dat voor genoemde disciplines plaats moet worden gemaakt in het bouwplan van de pathologie en wel met name in het deel, waarin de klinische pathologie gehuisvest is. Onzekerheid laat zich, wanneer men zich bewust is van de aard en de grenzen ervan, kwandificeren in termen van mate van warschinlikheid. Op dergelike wize bewerkte informatie vanuit de pathologie laat zich samen mel analoog bewerkte gegevens vanuil de kliniek combineren tot een model, waarmee de situatie van een individuele patiënt 20 goed mogelik kan worden benaderd en van waaruit optimaal verantwoorde beslissingen ten aanzien van de patient kumen worden genomen.

Schwartz en anderen hebben een lans gebroken voor een dergelijke zogenaamde probabilistische benadering in de pathologie, een benadering, die mijns inziens serieuze verdere studie verdient. Een voorwaarde hiervoor is well, dat de patholoog. meer dan thans het geval is, geneigd moet zijn in termen van patienten populaties te denken, waarvoor hij de hulp van de epidemiologie nodig heeft.

Ontwikelingen in de organisatie van de gezondheidszorg - en ik doel hierbij met name op de budgettering - zullen, naar ik verwacht, ook aan een attitude wijziging in deze zin bijdragen.

De heer Voemans van het ministerie van Welzijn. Volksgezondheid en Cultuur schetste in een lezing de visie van de overheid aldus: "Na de aandacht voor volumevergroting en differentiëring en uitbreiding van hel gezondheidszorgpakket in de wroegere "rijkere tijden' is Kwalliteitsbewordering nu het meest populaire van de onderwerpen, die in het tijdsgewricht van de kostenbeheersing spelen". Voorts stelt hij, dat "de adviezen van de commissie structuur en financiering gezondheidszorg (de commissie Dekker) steun geven aan de gedachte dat deze zorgverlening ook wel eens marklgevoelig zou kunnen zijn"."

Wat kan cleze veranderende wisie op de organisatie van de gezondheidszorg voor de patholoog-anatoom betekenen? Het laat zich aanzien, dat zich in de steer van onze diagnostische verrichtingen accentverschuivingen zullen gaan manifesteren. Tot ousverre werden deze activiteiten vooral gericht op de individuele patientenzorg. Tegen de achtergrond van de noodzakelije kostenbeheersing is het de vraag of puur vanuit deze optiek omvang en aard van onze huidige diagnostische bemoeienis gerechtvaardigd blifven. Patholoog-anatomen zullen zich moeten gaan afvragen. welke van hun activiteiten direct verband houden 
met het wel en wee van de individuele patent en van invloed zijn op het uit te stippelen beleid. De structurele voorzieningen zullen in elk geval zodanig moeten zijn, dat in die situaties een maximale toepassing van het diagnostisch arsenaal gegarandeerd blift. Hierbif is echter een evaluatie van de waarde van de extra lechnieken tegen de achtergrond van de bijdrage die zij leveren in het formuleren van een antwoord op de vanuit de kiniek gestelde vraag, op zijn plaats.

Protocollen, die aangeven, welke activiteiten hierbij essentieel zinn, zullen op grond van dergelijke besliskundige evaluaties moeten worden geformuleerd.

Wil dit zeggen, dat een deel van onze diagnostiek in de krimpsector terecht dreigt te komen? Ik geloof van niet, getuige ook de reeds aangegeven visie wan de overheid, waarin kwaliteitsbevordering centraal staat. De diagnostische activiteiten, die niet direct verricht worden in het kader wan de individuele patientenzorg. zullen een sterk kwaliteitsbewakend of bevorderend aspect kunnen krijgen. wanneer de patholoog zijn gegevens op epidemiologische wijze, d.w.z. meer op hell niveau van populaties van patienten, verwerkt. Ik voorzie daarom op het gebied van de klinische pathologie geen groei, wel verdergaande differentiatie.

Anders is het gesteld met de obductie. Een gecompliceerd samenspel van factoren, zowel van de kant van het publiek als van de beroepsbeoefenaren, op de details waarvan ik nu niet wil ingaan, heeft mondiaal geleid tot een onrustbarende daling in het percentage overledenen, dat ter obductie wordt aangeboden. In ons ziekenhuis constateerden wij bijvoorbeeld een daling van 49 naar $39 \%$ gedurende de afgelopen twee jaar. Vloemans vroeg zich in de reeds vermelde lezing af, wat de positie van de obductie overgelaten aan het vrije marktmechanisme - zou worden. Het is niet moeilik te bedenken, welk een dramatische ontwikkelingen ons in zo'n situatie te wachten staan. De effecten van de obductie als machtig instrument van kwaliteitsbewaking en bevordering zijn wijdverbreid, difuus, moeilijk direct meetbaar en slech in onderdelen op te splitsen. Bovendien worden de kosten op een andere plaals gemaakt dan de effecten waarneembaar worden en zit hierin tevens een soms ruim tijdsverschil. In deze karakteristiek zijn vrijwel alle elementen van een ypisch publieke zaak aan de orde gesteld. De overheid mag dan ook niet vanat de zijlijn toekijken, maar dient- juist in de situatie. waarbij het marktmechanisme een rol van betekenis in de organisatie van de gezondheidszorg gaat spelen - actief regulerend op te treden. Indien de ontwkkeling gaat in de richting van budgetten gebaseerd 
op dagnose gerelateerde groepen. zal hierin nadrukkelijk rumte voor het verrichten wan een obductie moeten worden gecreëerd. Ook zouden ziekenhuizen via sturing van het budget tot het streven naar hoge obduclie percentages geprikkeld kunnen worden.

Zo geraak ik, me als een patholoog-anatoom van vandaag de dag beschouwend, tot de paradoxale vaststelling, dat bepaalde facetten van onze diagnostische arbeid kunnen worden gerelativeerd, maar dat tegelikertid niet aan het belang van de obductie mag worden getornd. Ik hoop, dat de nuanceringen, die $k$ in min rede heb aangebracht, de schinbare tegenstrijdigheid in deze vaststelling voldoende aan U duidelijk hebben gemaakt. Dat er echter sprake is van een zekere spiraalbeweging in de oniwikkeling van de pathologie, kan niet worden ontkend.

Hoogleraren in de pathologie liken per traditie met een gerichtheid op onderwis in de geneeskunde behept te zijn. Zowel mijn vader als mini collega Bosman wijdden in hun inaugurele redes een omvangrijke paragraat aan het geven van hun visie op het medisch onderwijs.

Staal U ook mij toe - hoewel buiten de orde van de in de titel van deze rede aangegeven thematiek - enige woorden aan dit onderwerp te spenderen. Sinds een zevental jaren ben ik in allerlei rollen en functies betrokken bij ons unieke Maastrichtse onderwijssysteem. Op gevaar af na hetgeen ik nu ga zeggen als een onverbeterlijke tegenstrever te boek te worden gesteld, maar misschien enigszins als tegenwicht legen het vele positieve, dat terecht over het systeem naar buiten wordt gebracht, zou ik me thans willen beperken tot een enkele kritische kanttekening. Uit een onderzoek aan meendere medische faculteiten, waaronder de onze, bleek, dat in de loop der jaren aanzienlijke verschillen in kennisniveau wan de studenten bestaan. Aan het einde van de rit na zes jaar dus - bleken echter alle studenten hetzelfde niveau te hebben bereikt. Hoewel ik me realiseer, dat kennisniveau niet alles zegt over hel functioneren van een arts, durf ik deze studie als uitgangspunt te nemen voor de stellingname, dat de waarde van een onderwijssysteem gemeten in temen van de kwaliteit van het afgelewerde produkt sterk gerelativeerd mag worden.

Als het onderwissysteem voor de kwaliteit van de afgestudeerden van betrekkelik ondergeschikte waarde mag worden geacht. worden naar min mening secundaire omstandigheden. waaronder met name het plezier, waarmee men het onderwijs ondergaat, respectievelijk verstrekt, van belang in de beoordeling van de wijze, 16 waarop het onderwijs is georganiseerd. Polsen van de studenten, 
waarmee $k$ in aanraking kom, heeft mij wat dit betrefl geen onverdeeld gunstig beeld opgeleverd. Opvallend weing commentaar wordi aan deze instelling gehoord van de zije van de docenten omtrent het plezier, dat zij in hun onderwijsrollen en functies beleven. Ik denk desondanks, dat velen het met mij eens zullen zijn, als ik stel, dat ons Maastrichtse onderwijssysteem - om een modernisme le gebruken - weinig "docentvriendelik" is. Twee argumenten zijn aan le voeren voor het onderbouwen van deze stellingname. In de eerste plaats wordt de positie van hoorcolleges in het Maastrichtse systeem ingenomen door onderwisgroepen. waarin wan de docent niet een exclusief inhoudelike inbreng gevraagd wordt, maar de nadruk vooral ligt op een groepssturende functie. Gedurende de eerste jaren heb ik het aanschouwen van en het interacteren in groepdynamische situaties als een uitdagende ervaring beleefd, maar na enige tijd kwam ik tot de conclusie, dat dit voor een medisch gevormde toch weinig bevrediging opleverde. In de tweede plaats is onze onderwijsorganisatie zodanig gestructureerd, dat de verantwoordelijkheid voor de inhoudelike invulling van het curriculum in onevenredige mate wordt bepaald door mensen zonder een uitdrukkelijke onderwijsopdracht en niet medisch geschoolden.

Hierbij moet echter direct worden aangetekend, dat ons onderwijssysteem wel ruirnte laat voor direct contact tussen student en docent voor een deel in de steer van extracurriculaire activiteiten. Op de pathologie wordt van deze mogellikheid uitgebreid gebruik gemaakt. Ik vraag mij af, of het legaliseren van dit soort activiteiten door het instellen van een vrije beleidsruimte, zoals we die uit de onderzoekssector kenmen, in het onderwijs tof een betere motivatie van de docent zou kumnen leiden. In de loekomst hoop ilk de gelegenheid te kriggen min affiniteit voor medisch onderwis in organisatorische zin lot uitdrukking te brengen.

Mijn dank gaat uit naar hel College van Bestuur, dat mij benoemde tot hoogieraar in de pathologie en mij daarmee in staat heeft gesteld mijn carriere in Maastricht voort te zetten.

Hooggeleerde Bosman, beste Fré. Je naam is vanmiddag reeds enkele malen genoemd. Dit tekent onze intensieve samenwerking en goede verstandhouding. Tevens blikt eruit, hoe jij je stempel hebt gedrukt, niel alleen op de vakgroep als geheel, maar ook op de ontwikkeling van mijn persoonlike visie op het vak. Ondanks het geringe leeftidsverschil, dat tussen ons bestaat, beschouw ik je 
daarom voor een deel als min leermeester en zal er - voorlopig athans - van mij uit een zekere ahankelikheid in onze relatie bliven bestaan, iets wat ik overigens net als een bezwaar voor de verdere uitbouw van onze vakgroep ervaar. Integendeel, zou ik zelts willen stellen.

Hooggeleerde Swaen, beste Victor. Vreend genoeg heb ik me pas fijdens de voorbereiding van deze rede uitdrukkelijk gerealiseerd evenals mijn vader een Maastrichtse leermeester en voorganger te hebben gehad.

De gemoedelijke en cordiale steer, die je op de afdeling wist te scheppen, bood mij de gelegenheid me optimaal te ontplooien. Ik hoop voldoende van je te hebben geleerd om in staat te zijn bij te dragen aan de continuering van de unieke intercollegiale verstandhouding, die ondanks je vertrek nu reeds twee jaar geleden nog steeds op de afdeling bestaat. Je betrokkenheid bij de patiëntenzorg heeft aan mijn vorming tot klinisch patholoog de beslissende stimulans gegeven. Ik beschouw het daarom als een eer in je voetsporen te mogen treden.

Hooggeleerde van Breda Vriesman, beste Peter. Je visie op de pathologie vanuit de kliniek is vaak complementair aan die van een patholoog. Dat onze vakgroep - mede door mijn toedoen - niet in zijn oorspronkelijke constellatie heeft kunnen blijven voonbestaan. betreur ik daarom achteraf gezien sterk.

Collegae Hoogleraren.

Met velen uwer heb ik in het verleden reeds in allerlei situaties mogen samenwerken. Ik hoop dit in de toekomst op dezelfde wijze te kunnen voortzetten.

Darnes en Heren Collegae van het bestuur van de Nederlandse Patholoog Anatomen Vereniging.

Ik voel mij bevoorrecht zo vroeg reeds in mijn carrière als patholoog in staal gesteld te zijn bij te dragen aan de vormgeving van de pathologie in Nederland.

In het bizonder. Hooggeleerde Hoedemaeker, beste Flip, verheugt mij- mede gezien de link uit het verteden - de uiterst plezierige samenwerking: die ik de atgelopen twee jaar met je heb gehad. 
Dames en Heren Leden van Bestuur en Direclie van het Acaclemisch Ziekenhuis.

Ik hoop, dat wij in staat zullen zijn een constructie te vinden, die wia een directe communicatie leidt tot een goede samenwerking.

Collegae en Leden van de vakgroep Pathologie.

De wijze, waarop jullie iemand, die uit jullie midden afkomstig is, niet alleen in een andere verhouding hebben geaccepteerd. maar daatoe zelfs enigszins hebben aangemoedigd, is voor mij reden geweest de laatsle aarzeling bij het aanvaarden van het hoogleraarschap te laten varen.

De steer, waarin wij in de gewijzigde situatie ook thans nog met ekaar omgaan, garandeert een vruchbare samenwerking in de toekomst. Namen wil ik in dit verband niel noemen, maar één uitzondering wil ik maken voor Rob Visser.

Rob, mede door de unieke opleidingssituatie, waarin wil ons met zijn tweeen bevonden onder de veugels van Swaen is er tussen ons een meer dan collegiale verstandhouding gegroeid. Ook vanmidaag geef je hieraan weer op je geheel eigen wijze uiting.

Collegae pathologen uit de regio.

Euregio mag ik met enige trots zeggen varwege het reguliere bezoek van Duitse en Belgische collegae aan onze maandelijkse coupe-avonden, die hiermee een bijdrage leveren tot het realiseren van een wan de aspiraties van deze instelling.

De tijd ontbrak mij vanmiddag te benadrukken, dat ik verwacht, dat regionale samenwerking in de ontwikkeling van de pathologie een zwaartepunt zal vormen met name met het oog op kwalieitsbewaking en kwaliteitsbevordering. Binnen onze harmonieuze verhoudingen floreren de coupe-awonden en is vorig jaar een begin gemaakt met een nu reeds goed functionerend lymtomenpanel. Meer panels zullen ongelwijteld volgen. Ik ben ervan overtuigd, dal de wize, waarop wil onze regionale activiteiten structureren en worm geven aan de rest van ons land ten voorbeeld kunnen worden gesteld.

Moge dit in de toekomst zo blijuen!

Itk dank U voor uw aandacht 